\title{
Effect of Production System and Age on Egg Quality Parameters: A Case of Niğde Province Çamardı District, Turkey
}

\author{
Emine Polat Yurtseven ${ }^{1, a}$, Ahmet Şekeroğlü ${ }^{1, b^{*}}$, Brian Tainika ${ }^{1, c}$, Mustafa Duman,d, Yunus Emre Şentürk,e \\ ${ }^{I}$ Department of Animal Production, Faculty of Agricultural Sciences and Technologies, Niğde Ömer Halisdemir University, 51240 Niğde, Turkey. \\ ${ }^{2}$ Department of Laboratory and Veterinary Health, Bor Vocational School, Niğde Ömer Halisdemir University, 51240 Niğde, Turkey.
} *Corresponding author

\section{A R T I C L E I N F O A B S T R A C T}

Research Article

This study compared egg quality parameters in layers under free-range system with prefabricated pens and backyard while emphasizing hen age. A total of 300 eggs collected from prefabricated pens and backyard farming families in the Çamardı District of Niğde Province were used as study materials. The assessed external and internal egg quality characteristics included egg weight, shape

Received : 01/02/2021

Accepted : 21/04/2021 index, shell thickness, shell breaking strength, albumen index, Haugh unit, yolk index, and yolk colour. The effect of production system on albumen index, Haugh unit, and yolk colour score was found statistically significant. There was a significant effect of age on shape index, shell thickness, shell breaking strength, albumen index, Haugh Unit, yolk index, and yolk colour score. The effect of interaction between age and production system was statistically significant for shape index, shell thickness, yolk index, Haugh Unit, and yolk colour score. It was determined that the egg`s meat and blood spots percentages from the free-range and backyard systems were $10.6 \%$ and $15.3 \%$, respectively. It was concluded that while eggs produced from free-range system are superior in terms of egg weight, shape index, and Haugh unit those obtained from backyard hens are higher in eggshell thickness, eggshell breaking strength, and egg yolk colour.

Alternative chicken production Backyard chicken Egg quality Free-range system Laying hen

\begin{tabular}{ll|l} 
& & \\
\hline a@ eminepolat_sgm@hotmail.com & (i) http://orcid.org/0000-0001-6662-536X & bahmet.sekeroglu@ohu.edu.tr \\
c@ tainika2012b@yahoo.com & (i) https://orcid.org/0000-0001-6785-4324 & d@mustafa.duman@ohu.edu.tr \\
e@ yemresenturk35@gmail.com & (i) http://orcid.org/0000-0002-9218-5254
\end{tabular}

\section{Introduction}

The demand for chicken products such as eggs has increased in parallel with change in socio-economic and demographic profiles, rapid and increased urbanization, accelerated population growth in cities, and industrialization (Henchion et al., 2017). It is established that in the 20th century the above factors influenced the transition from traditional to industrial chicken production systems. The traditional production system composed of the backyard (510 birds), and free-roaming chickens to meet the egg and meat needs of families.

In several developed countries, accelerated transitions in the layer chicken industry including hen intensification and genetic improvement of laying hens were observed after the 1960s (Tainika and Şekeroğlu, 2020). Today, commercial laying hen hybrids have achieved an annual egg yield of 310-330 eggs with feed conversion rates of 2.1-2.3 (Hocking, 2015). During this period, the developed battery cage production system for laying hens has played an important role in meeting the need for eggs. Meanwhile, this led to the emergence of behavioral and welfare problems especially metabolic disorders and skeletal disorders, and the intensive laying hen production system has been criticized for failing to meet the basic needs of chickens (Șekeroğlu and Diktaș, 2012). Battery cage production system is highlighted for insufficient space and restricted movement that compromises hen's ability to express natural behaviors (Widowski et al., 2016; Scrinis et al., 2017; Rohlf et al., 2019).

In a survey, Żakowska-Biemans and Tekień (2017) identified that eggs produced from free-range had a higher comparable significance to consumers than organic eggs although the latter is majorly known for high hen welfare standards. Furthermore, as a factor affecting egg quality, hen welfare has become an increasingly important marketing strategy (Widmar et al., 2020; Tufarelli et al., 2018). Due to these market reactions powered by increased consumer perception in the world, alternative chicken production systems including free-range that prioritize hen welfare have 
been enhanced (Tufarelli et al., 2018; Ochs et al., 2018). The free-range system is characterized by ease of movement, enough space, outdoor access that enables the hens to perform their natural behaviors in addition to exposure to sunlight, and free diets like small insects and forage. Production systems highly influence egg quality and performance characteristics (Englmaierová et al., 2014; Lordelo et al., 2017; Philippe et al., 2020), and consumers are interested in the price and nutritional value of poultry products, as well as quality criteria such as hygiene, food safety, colour, aroma, flavour, etc (Rondoni et al., 2020).. Samiullah et al. (2017) determined that the eggs from the free-range system were superior to other systems for shell weight, albumen index, and Haugh unit, and an earlier study by Lewko and Gornowicz (2011) reported the highest shell weight and thickness for freerange eggs. On the contrary, Yenice et al. (2016) identified lower albumen index and Haugh unit values in free-range eggs compared to cage eggs. In one study, yolk colour values were higher in free-range eggs as opposed to other systems (Samiullah et al. 2014). Significant values of albumen quality and yolk index of free-range eggs compared with litter system were found by Mohammed et al. (2013). Sarica et al. (2021) stated that farmers perceive eggs from a backyard chicken are superior in terms of quality and health compared with other commercial systems. However, studies regarding the egg quality in backyard chickens are rare yet the system is still common among the rural communities due to the above perceptions. Therefore, the current study compared egg quality in freerange and backyard systems while considering the effect of flock age.

\section{Material and Method}

The study was conducted between December 2019 and April 2020 using eggs obtained from 10 enterprises (5 from each of free-range egg and backyard chicken enterprises) in Çukurbağ, Demirkazık, and Orhaniye villages of Çamardı district of Nigde Province, Turkey. The province is located in the Central Anatolia region of Turkey at an altitude of $1299 \mathrm{~m}\left(37^{\circ} 58^{\prime} 00^{\prime \prime} \mathrm{N} 34^{\circ} 40^{\prime} 45^{\prime \prime} \mathrm{E}\right)$. The study did not involve animal rearing but a brief description of the two production systems is given below.

\section{Animal Material and Husbandry}

The animal material comprised of ATAK-S layer hybrids (Turkish developed breed) in the free-range system, while in backyard system, hens were local brown layers Within farming families. Under the free-range system, 250 hens were housed in prefabricated pens of 32 $\mathrm{m}^{2}(4 \times 8 \mathrm{~m})$, including an outdoor area of $1000 \mathrm{~m}^{2}$. There were 2 lines of 7-meter nipple drinkers, 36 nest boxes, and 5 feeders each with a capacity of $12 \mathrm{~kg}$. The hen pens had 2 windows providing ventilation and lighting. Water and feeds were provided without restriction and access to outdoor area was adjusted according to daily weather conditions and day length, and the stocking density was 4 hens $/ \mathrm{m}^{2}$.

The number of chickens in backyard system, the pens, and outdoor areas varied with the possibilities and did not have a specific standard (uncontrolled environmental village conditions).
In both systems, hens were fed layer feeds containing $88 \% \mathrm{KM}, 16 \%$ crude protein, and $2750 \mathrm{kcal} / \mathrm{kg}$ metabolic energy produced by various commercial trademarks. Besides, there was feed supplementation with forage and wheat grains during summer and winter, respectively. Furthermore, natural and artificial lighting was used depending on the day length however, a specific lighting program was not applied.

The hens under free-range system were obtained from a commercial business and until the 17th-week, vaccination against Marek, Newcastle, Gumbaro, and Infectious Bronchitis was completed. In backyard system, farmers obtained chicks themselves from fertilized eggs using an incubator, and no effective health protection program was implemented.

\section{Egg Samples}

The eggs used in the study were produced from hens between 25-30, 33-38, and 40-46 weeks of age with an interval of 8 weeks. A total of 10 eggs were randomly selected from each of the 5 enterprises in both systems, and this process was repeated for each age group. At the end of the trial, a total of 300 eggs were used (150 eggs from each production system).

\section{Egg Quality Analyses}

The eggs were collected from the enterprises and brought to the Egg Quality Analysis Laboratory of the Department of Animal Production and Technologies of Niğde Ömer Halisdemir University. The eggs were stored at room temperature for 24 hours before the analysis. Apart from the albumen height and yolk colour score that were automatically detected with an egg analyzer device (Orka food technology), all the other egg quality traits were determined according to Şekeroğlu et al. (2014). Briefly, after 24 hours of storage, egg weight was measured with a precision balance (sensitivity of $0.01 \mathrm{~g}$ ). Egg width and length were taken with a digital calliper to find the shape index (SI) values with the formula below.

$$
\mathrm{SI}=(\text { Egg width } / \text { Egg length }) \times 100 \text {. }
$$

Eggshell breaking strength was measured with an egg force reader branded measuring device (Orka food and technology).

The inner membranes of the shell samples taken from the blunt, middle, and pointed part of the broken eggs were removed, and the shell thickness was determined with a $1 / 100 \mathrm{~mm}$ sensitive micrometer.

Then, albumen and yolk width and length, and yolk diameter were measured on the glass table with a digital caliper $( \pm 0.001 \mathrm{~mm})$. The values obtained from above were used to calculate albumen and yolk index (AI and YI, respectively), and Haugh unit with the formulas below;

$$
\begin{gathered}
\mathrm{AI}=(\mathrm{AH}(\mathrm{mm}) /(\mathrm{AL}(\mathrm{mm})+\mathrm{AW}(\mathrm{mm})) / 2)) \times 100 \\
\mathrm{YI}=\mathrm{YH}(\mathrm{mm}) /(\mathrm{YD}(\mathrm{mm})) \times 100
\end{gathered}
$$

$$
\text { Haugh Unit = } 100 \log \left(\mathrm{AH}+7.57-1.7 \mathrm{G}^{0.37}\right) \text {, }
$$

AH : Albumen height (mm),

AL : Albumen length

AW : Albumen width

YH : Yolk height

YD : Yolk diameter

G : Egg weight $(\mathrm{g})$. 


\section{Statistical Analysis}

All data was shown as the mean \pm standard error (SE) and analysed by the General Linear Model procedure of SPSS software version 18. The data of egg quality characteristics was checked for normality and homogeneity of variance, of which data in line with the normal distribution was analysed by 1-way analysis of variance (ANOVA). Duncan's multiple range test was used to analyse mean difference among groups when significance $(\mathrm{P}<0.05)$ was identified. All values with $(\mathrm{P}<0.05)$ were considered statistically significant. The identified egg`s meat and blood spots were calculated as percentages.

\section{Results}

\section{Effect of Production System}

The effect of production system on external egg quality parameters (egg weight, shape index, shell thickness, and eggshell breaking strength), and internal egg quality characteristics (albumen index, Haugh unit, and yolk colour score) was statistically significant $(\mathrm{P}<0.01)$. Egg`s meat and blood spots percentages were $10.6 \%$ and $15.3 \%$ for free-range and backyard laying hen production systems, respectively.

\section{Effect of Age}

Age effect on external egg quality features (shape index, shell thickness, eggshell breaking strength) and internal egg quality parameters (Albumen index, Haugh Unit, yolk index, yolk colour score) was found significant $(\mathrm{P}<0.01 ; \mathrm{P}<0.05)$. The effect of interaction between age and production system was significant for shape index, shell thickness, Haugh Unit, yolk index, and yolk colour score $(\mathrm{P}<0.01 ; \mathrm{P}<0.05)$. All the findings of the study are shown in Table 1 and Table 2.

\section{Discussion}

This study evaluated the differences in egg quality parameters between free-range and backyard hens at different ages. Although the effect of age on egg weight was not significant in this study, we determined that egg weight increased with advancing hen`s age in the freerange system. This is similar to a study by Bari et al. (2020) when the authors investigated the effect of early rearing enrichments on some egg quality parameters in free-range layers. Furthermore, various studies have reported that there was an increase in egg weight with advancing hen`s age (Yılmaz Dikmen et al., 2017; Vlčková et al., 2019; Kraus et al., 2021). Also, we identified that eggs from freerange layers were heavier than those in the backyard system. The similar result was identified by Yenice et al. (2016). It is thought that free-range system may be less affected by environmental factors since it is more controlled than the backyard in addition to the genotypes used. Several authors have reported that environment and laying hen genotype are some of the factors that impact egg weight (Van Den Brand et al., 2004; Sirri et al., 2018; Zita et al., 2018).
In the present study, there was a significant effect of production system, age, and the interaction of age and production system on shape index. In agreement, several studies observed that there is a significant effect of production system on shape index (Englmaierová et al., 2014; Zita et al., 2018). In contrast to our study, Molnar et al. (2016) identified that there was no effect of hen`s age on shape index. Also, Hanusova et al. (2015) determined that there was no significant difference in shape index between eggs from two dual-purpose breeds. However, Yenice et al. (2016) found that there was a greater shape index in eggs from free-range hens than those in the backyard. We assumed that the shape index could as well be affected by the breeds used in the various production systems thus, a possible reason for the observed significant effect of production system in the current study. Sokołowicz et al. (2019) reported that there was a significant effect of hen genotype on shape index. The significant effect of age on shape index could be associated with increasing egg weight and a statistically significant positive correlation between egg weight and shape index has been reported by Duman et al. (2016).

We found that the average eggshell thickness was higher in eggs from the backyard system. Furthermore, the overall effect of production system and the interaction of age with the production system on eggshell thickness was significant. The statistical significance of age and production system interaction was linked to the hen age. In agreement, Petek et al. (2009) observed that there was a significant difference in eggshell thickness for production systems and age but on the contrary, they found that there was no significant effect of interaction between age and production system on eggshell thickness. Also, Van Den Brand et al. (2004) identified that there was no significant difference in shell thickness between production systems, and in eggs from the outdoor system, shell thickness increased or was constant with increasing hen`s age. The above authors recommended that an eggshell - housing system be used as a bio-indicator for laying hen management. Yenice et al. (2016) determined that the shell thickness of free-range eggs was higher compared with backyard system, and these conflicts with the present study. We argue that different genotypes were used in the production systems in the present study thus, the effect of production system on eggshell thickness could be associated with breed effect. A study by Hanusova et al. (2015) found that there was a significant difference in eggshell thickness between breeds.

We observed that eggshell breaking strength was significantly affected by the production system and age though higher in eggs from the backyard system. Furthermore, the effect of interaction between age and production system was not significant for eggshell breaking strength. Petek et al. (2009) found a similar effect of age and age-housing system interaction for eggshell strength however, the effect of housing system was in disagreement with the present study. Similarly, Bari et al. (2020) identified that there was no significant effect of production system on eggshell breaking strength which is contrary to the current study. 
Table 1 . The effect of production system on internal and external quality characteristics

\begin{tabular}{|c|c|c|c|c|}
\hline \multirow{2}{*}{ Trait } & \multicolumn{2}{|c|}{ Production system } & \multirow{2}{*}{ SEM } & \multirow{2}{*}{ P-value } \\
\hline & Free-range & Backyard & & \\
\hline Egg weight (g) & $62.94^{\mathrm{a}}$ & $58.33^{\mathrm{b}}$ & 0.46 & 0.01 \\
\hline Shape index (\%) & $74.86^{\mathrm{a}}$ & $76.42^{\mathrm{b}}$ & 0.27 & 0.01 \\
\hline $\operatorname{EST}(\mathrm{mm})$ & $0.34^{\mathrm{a}}$ & $0.37^{\mathrm{b}}$ & 0.02 & 0.01 \\
\hline $\operatorname{EBS}\left(\mathrm{kg} / \mathrm{cm}^{2}\right)$ & $3.40^{\mathrm{a}}$ & $4.10^{\mathrm{b}}$ & 0.07 & 0.01 \\
\hline Albumen index $(\%)$ & $5.95^{\mathrm{a}}$ & $4.93^{\mathrm{b}}$ & 0.16 & 0.01 \\
\hline Haugh Unit & $62.81^{\mathrm{a}}$ & $57.73^{\mathrm{b}}$ & 1.20 & 0.01 \\
\hline Yolk index $(\%)$ & 47.49 & 44.92 & 0.89 & 0.05 \\
\hline Yolk colour score $(\%)$ & $9.64^{\mathrm{a}}$ & $10.19^{b}$ & 0.12 & 0.01 \\
\hline $\operatorname{MBS}(\%)$ & 12.95 & 14.30 & & \\
\hline
\end{tabular}

$\overline{\mathrm{a}, \mathrm{b}}$ Values within a row with different superscripts differ significantly at $\mathrm{P}<0.05$. Abbreviations: SEM, standard error of the mean; EST, eggshell thickness; EBS, eggshell breaking strength; MBS, meat and blood spots

Table 2. The effect of production system, age and age production system interaction on internal and external quality characteristics

\begin{tabular}{|c|c|c|c|c|c|c|c|}
\hline \multirow{2}{*}{ Trait } & \multirow{2}{*}{ A (week) } & \multicolumn{2}{|c|}{ PS } & \multirow{2}{*}{ Mean } & \multirow{2}{*}{ SEM } & \multirow{2}{*}{$\mathrm{P}(\mathrm{A})$} & \multirow{2}{*}{$\mathrm{P}(\mathrm{A} \times \mathrm{PS})$} \\
\hline & & FR & VP & & & & \\
\hline \multirow{3}{*}{ Egg weight (g) } & $25-30$ & 62.89 & 57.24 & 60.06 & \multirow{3}{*}{1.82} & \multirow{3}{*}{0.05} & \multirow{3}{*}{0.05} \\
\hline & $33-38$ & 61.60 & 59.18 & 60.39 & & & \\
\hline & $40-46$ & 64.33 & 58.56 & 61.44 & & & \\
\hline \multirow{3}{*}{ Shape index $(\%)$} & $25-30$ & 73.94 & 75.46 & $74.70^{\mathrm{a}}$ & \multirow{3}{*}{0.33} & \multirow{3}{*}{0.01} & \multirow{3}{*}{0.05} \\
\hline & $33-38$ & 75.03 & 77.80 & $76.42^{\mathrm{b}}$ & & & \\
\hline & $40-46$ & 75.62 & 75.99 & $75.80^{\mathrm{b}}$ & & & \\
\hline \multirow{3}{*}{ EST (mm) } & $25-30$ & 0.34 & 0.36 & $0.35^{\mathrm{a}}$ & \multirow{3}{*}{0.07} & \multirow{3}{*}{0.05} & \multirow{3}{*}{0.05} \\
\hline & $33-38$ & 0.32 & 0.38 & $0.35^{\mathrm{a}}$ & & & \\
\hline & $40-46$ & 0.36 & 0.38 & $0.37^{b}$ & & & \\
\hline \multirow{3}{*}{$\operatorname{EBS}\left(\mathrm{kg} / \mathrm{cm}^{2}\right)$} & $25-30$ & 3.44 & 3.90 & $3.67^{\mathrm{a}}$ & \multirow{3}{*}{0.09} & \multirow{3}{*}{0.01} & \multirow{3}{*}{0.05} \\
\hline & $33-38$ & 2.97 & 3.97 & $3.47^{\mathrm{a}}$ & & & \\
\hline & $40-46$ & 3.78 & 4.44 & $4.11^{\mathrm{b}}$ & & & \\
\hline \multirow{3}{*}{ Albumen index (\%) } & $25-30$ & 4.47 & 5.52 & $4.99^{\mathrm{a}}$ & \multirow{3}{*}{0.19} & \multirow{3}{*}{0.01} & \multirow{3}{*}{0.05} \\
\hline & $33-38$ & 7.24 & 3.33 & $5.28^{\mathrm{a}}$ & & & \\
\hline & $40-46$ & 6.13 & 5.95 & $6.04^{\mathrm{b}}$ & & & \\
\hline \multirow{3}{*}{ Haugh Unit } & $25-30$ & 51.58 & 61.86 & $56.92^{\mathrm{a}}$ & \multirow{3}{*}{1.46} & \multirow{3}{*}{0.01} & \multirow{3}{*}{0.01} \\
\hline & $33-38$ & 71.72 & 46.82 & $59.27^{\mathrm{a}}$ & & & \\
\hline & $40-46$ & 64.74 & 64.52 & $64.63^{\mathrm{b}}$ & & & \\
\hline \multirow{3}{*}{ Yolk index (\%) } & $25-30$ & 48.08 & 48.04 & $48.06^{\mathrm{b}}$ & & & \\
\hline & $33-38$ & 47.68 & 39.42 & $43.55^{\mathrm{a}}$ & 0.97 & 0.05 & 0.05 \\
\hline & $40-46$ & 46.72 & 47.30 & $47.01^{\mathrm{b}}$ & & & \\
\hline & $25-30$ & 10.22 & 10.60 & $10.41^{\mathrm{c}}$ & & & \\
\hline YCS (\%) & $33-38$ & 8.92 & 10.04 & $9.41^{\mathrm{a}}$ & 0.15 & 0.01 & 0.05 \\
\hline & $40-46$ & 9.94 & 9.92 & $9.93^{b}$ & & & \\
\hline
\end{tabular}

\footnotetext{
$\overline{a, b, c}$ Values within a row with different superscripts differ significantly at P<0.05. Abbreviations: EST, eggshell thickness; YCS, yolk colour score; EBS eggshell breaking strength; A, age; PS, production system; FR, free-range; VP, backyard; SEM, standard error of the mean; A $\times$ PS, age - production system interaction
}

However, they determined that there was no significant effect of age and production system interaction on eggshell breaking strength which is in line with our study. Yenice et al. (2016) stated that free-range eggs had a higher eggshell breaking strength compared with backyard in contrast to the current study. Similarly, Kraus et al. (2021) determined a significant effect of production system, age, and age production system interaction for eggshell thickness.

According to Lewko and Gornowicz (2011), the main determinant of table egg quality is albumen quality (albumen height and Haugh Unit) and is mainly affected by age besides the production system. In the present study, the effect of production system, age, and age - production system interaction on albumen index and Haugh unit was significant determined as significant. Also, as age advanced, albumen index and Haugh unit decreased. In agreement, Doyon et al. (1985) found that flock age was inversely proportional to albumen height and Haugh unit. We found the highest Haugh unit (64.74) in eggs from both systems, and this is much lower compared with what was reported in several studies (Yenice et al., 2016; Sirri et al., 2018; Zita et al., 2018; Hanusova et al., 2015). Furthermore, in agreement with the present study, several studies found that there was a significant effect of production system on Haugh unit (Lewko and Gornowicz, 2011; Englmaierová et al., 2014; Samiullah et al., 2014). In the current study, the albumen index in free-range and backyard system eggs was 5.95 and $4.93 \%$, respectively versus 5.68 and $6.05 \%$ (Yenice et al., 2016). These values are lower than those reported in various studies (Hanusova et al., 2015; Kraus et al., 2021). 
Yolk quality is determined by the yolk index. In the current study, were identified that there was a statistically significant and no significant difference of production system, age, and age-production system interaction, respectively in the yolk index. In parallel with the study, Petek et al. (2009) determined that the effect of production system on yolk index was not significant however, Englmaierova et al. (2014) and Mohammed et al. (2013) stated that the effect of production system was significant for the yolk index.

Egg yolk colour is one of the important egg interior quality characteristics, and the demand for yolk colour may vary according to the consumer`s preferences. The effect of production system on yolk colour score was statistically significant, and the scores for eggs obtained from the backyard system were found higher as opposed to freerange. In agreement, Yenice et al. (2016) reported that the yolk colour score for eggs from the backyard system is superior compared with free-range. This supported the consumer's perception that eggs produced from backyard hens have darker coloured yolks compared with the commercial systems. However, Sarica et al. (2021) reported that the consumer's belief that the level of the darker yolk colour is the same both in village type and the free-range system was not true. The effect of age and ageproduction system interaction for yolk colour was found significant. Petek et al. (2009) identified a similar effect of age for yolk colour but the effect of age-production interaction on yolk colour was in contrast with the present study. Meat and blood spots in egg content are significant internal quality criterion that affects consumer demand. We observed that meat and blood spot values in the eggs obtained in the free-range were lower than in the village system. Genetic factors were thought to be the main causes of high egg meat and blood spots in the village laying hen system though the spots are known to be influenced by other factors such as stress during ovulation, uncontrolled nutrition, vitamin deficiency, and infectious diseases. Furthermore, Nalbandov and Card (1944) stated that blood and meat spots in eggs increase in summer, and these spots in eggs are influenced by laying hen housing and floor conditions.

In conclusion, for external quality properties, while the free-range system outperforms in shape index and egg weight, the backyard system is dominant in shell thickness, shell strength, and yolk colour score. The free-range system is superior in all the internal egg quality characteristics excluding yolk colour. Thus, the system is better for desired quality parameters such as albumen index (a measure of freshness), Haugh Unit, yolk index, and meat and blood spots percentages.

Age and production system caused increasing and decreasing effects in some egg quality features. It is thought that this may be due to changing climatic and housing conditions, nutritional variations, vitamin and mineral deficiencies, infectious diseases, and genetic differences in animals used.

\section{Acknowledgments}

The authors acknowledge the support from the Turkish Council of Higher Education.

\section{Conflict of Interest}

The authors declare they have no conflict of interest.

\section{References}

Bari MS, Cohen-Barnhouse AM, Campbell D. 2020. Early rearing enrichments influenced nest use and egg quality in free-range laying hens. Animal, 14(6): 1249-57. doi.org/10.1017/S1751731119003094.

Doyon G, Bernier-Cardou M, Hamilton RM, Castaigne F, MacLean H. 1985. Egg quality. 1. Shell strength of eggs from five commercial strains of white leghorn hens during their first laying cycle. Poultry Science, 64(9): 1685-95. doi.org/10.3382/ps.0641685.

Duman M, Sekeroglu A, Yildirim A, Eleroglu H, Camci O. 2016. Relation between egg shape index and egg quality characteristics. European Poultry Science, 80:1-9. doi.org/10.1399/eps.2016.117.

Englmaierová M, Tůmová E, Charvátová V, Skřivan M. 2014. Effects of laying hens housing system on laying performance, egg quality characteristics, and egg microbial contamination. Czech Jornal of Animal Science, 59(8): 345-352.

Hanusova E, Hrnčár C, Hanus A, Oravcova M. 2015. Effect of breed on some parameters of egg quality in laying hens. Acta fytotechnica et zootechnica, 18(1): 20-4. doi.org/10.15414/ afz.2015.18.01.20-24.

Henchion M, Hayes M, Mullen AM, Fenelon M, Tiwari B.2017. Future protein supply and demand: strategies and factors influencing a sustainable equilibrium. Foods, 6(7): 53. doi.org/10.3390/foods6070053.

Hocking PM. 2015. Contribution of genetic selection and breeding structures to the economic development of the poultry industry. In, Proceedings of 3rd International Poultry Meat Congress. 22- 26 July, Antalya, Turkey.

Kraus A, Zita L, Krunt O, Härtlová H, Chmelíková E. 2021. Determination of selected biochemical parameters in blood serum and egg quality of Czech and Slovak native hens depending on the housing system and hen age. Poultry Science, 100(2): 1142-1153. doi.org/10.1016/j.psj.2020. 10.039.

Lewko L, Gornowicz E. 2011. Effect of housing system on egg quality in laying hens. Annals of Animal Science, 11(4): 60711. doi.org/10.2478/v10220-011-0012-0.

Lordelo M, Fernandes E, Bessa RJ, Alves SP. 2017. Quality of eggs from different laying hen production systems, from indigenous breeds and specialty eggs. Poultry Science, 96(5): 1485-91. doi.org/10.3382/ps/pew409.

Mohammed KA, Sarmiento-Franco L, Santos-Ricalde R, SolorioSanchez JF. 2013. Egg production, egg quality and crop content of Rhode Island Red hens grazing on natural tropical vegetation. Tropical animal health and production, 45(2): 367-72. doi.org/10.1007/s11250-012-0225y.

Molnar A, Maertens L, Ampe B, Buyse J, Kempen I, Zoons J, Delezie AE. 2016. Changes in egg quality traits during the last phase of production: is there potential for an extended laying cycle? British Poultry Science, 57(6): 842-7. doi.org/10.1080/00071668.2016.1209738.

Nalbandov AV, Card LE. 1944. The problem of blood clots and meat spots in chicken eggs. Poultry Science, 23(3): 170-80. doi.org/10.3382/ps.0230170.

Ochs DS, Wolf CA, Widmar NJ, Bir C. 2018. Consumer perceptions of egg-laying hen housing systems. Poultry Science, 97(10): 3390-6. doi.org/10.3382/ps/pey205.

Petek M, Alpay F, Gezen SS, Cibik R. 2009. Effects of housing system and age on early-stage egg production and quality in commercial laying hens. Kafkas Universitesi Veteriner Fakultesi Dergisi, 15: 57-62. doi.org/10.9775/kvfd.2008.65-A. 
Philippe FX, Mahmoudi Y, Cinq-Mars D, Lefrançois M, Moula N, Palacios J, Pelletier F, Godbout S. 2020. Comparison of egg production, quality and composition in three production systems for laying hens. Livestock Science, 232: 103917. doi.org/10.1016/j.livsci.2020.103917.

Released SI. 2008. SPSS statistics for windows, version 17.0. Chicago: SPSS Inc

Rohlf VI, Howell TJ, Coleman G, Rault JL. 2019. Engagement through online discussion: perceptions of laying hen welfare in furnished cages. Animal, 13(9): 1999-2006. doi.org/10. 1017/S1751731118003427.

Rondoni A, Asioli D, Millan E. 2020. Consumer behaviour, perceptions, and preferences towards eggs: A review of the literature and discussion of industry implications. Trends in Food Science and Technology, 106: 391-401. doi.org/ 10.1016/j.tifs.2020.10.038.

Samiullah S, Roberts JR, Chousalkar KK. 2014. Effect of production system and flock age on egg quality and total bacterial load in commercial laying hens. Journal of Applied Poultry Research, 23(1): 59-70. doi.org/10.3382/japr.201300805.

Samiullah S, Omar AS, Roberts J, Chousalkar K. 2017. Effect of production system and flock age on eggshell and egg internal quality measurements. Poultry Science, 96(1): 246-258. doi.org/10.3382/ps/pew289.

Sarıca M, Erensoy K, Özsoy Aİ. 2021. Fertility of Uncontrolled Village Flock Eggs and Comparison of Quality Traits of Table-Eggs Produced in Different Production Systems. Turkish Journal of Agriculture-Food Science and Technology, 9(2): 356-361. doi.org/10.24925/turjaf.v9i2. 356-361.4004.

Scrinis G, Parker C, Carey R. 2017. The caged chicken or the free-range egg? The regulatory and market dynamics of layerhen welfare in the UK, Australia and the USA. Journal of Agricultural and Environmental Ethics, 30(6): 783-808. doi.org/10.1007/s10806-017-9699-y.

Șekeroğlu A, Dİktaș M. 2012. Effect of free fange production system on slower-growing broiler carcass characteristics and meat quality. Kafkas Üniversitesi Veteriner Fakültesi Dergisi, 18(6): 1007-1013. doi.org/10.9775/kvfd.2012.6922.

Şekeroğlu A, Duman M, Tahtalı Y, Yıldırım A, Eleroğlu H. 2014 Effect of cage tier and age on performance, egg quality and stress parameters of laying hens. South African Journal of Animal Science, 44(3): 288-297. doi.org/10.4314/sajas. v44i3.11.

Sirri F, Zampiga M, Soglia F, Meluzzi A, Cavani C, Petracci M. 2018. Quality characterization of eggs from Romagnola hens, an Italian local breed. Poultry Science, 97(11): 4131-4136. doi.org/10.3382/ps/pey275.
Sokołowicz Z, Dykiel M, Krawczyk J, Augustyńska-Prejsnar A. 2019. Effect of layer genotype on physical characteristics and nutritive value of organic eggs. CyTA-Journal of Food, 17(1): 11-19. doi.org/10.1080/19476337.2018.1541480.

Tainika B, Şekeroğlu A. 2020. Effect of Production Systems for Laying Hens on Hen Welfare. 2020. Turkish Journal of Agriculture-Food Science and Technology, 8(1): 239-245. doi.org/10.24925/turjaf.v8i1.239-245.3151.

Tufarelli V, Ragni M, Laudadio V. 2018. Feeding forage in poultry: a promising alternative for the future of production systems. Agriculture, 8(6): 81. doi.org/10.3390/agriculture 80 60081.

Van Den Brand H, Parmentier HK, Kemp AB. 2004. Effects of housing system (outdoor vs cages) and age of laying hens on egg characteristics. British Poultry Science, 45(6): 745-752. doi.org/10.1080/00071660400014283.

Vlčková J, Tůmová E, Míková K, Englmaierová M, Okrouhlá M, Chodová D. 2019. Changes in the quality of eggs during storage depending on the housing system and the age of hens. Poultry Science, 98(11): 6187-6193. doi.org/10.3382/ps/pez 401.

Widmar N, Bir C, Wolf C, Lai J, Liu Y. 2020. \# Eggs: social and online media-derived perceptions of egg-laying hen housing. Poultry Science, 99(11): 5697-5706. doi.org/10.1016/j.psj. 2020.07.011.

Widowski TM, Hemsworth PH, Barnett JL, Rault JL. 2016. Laying hen welfare I. Social environment and space. World's Poultry Science Journal, 72(2): 333-342. doi.org/10.1017/ S0043933916000027.

Yenice G, Kaynar O, Ileriturk M, Hira F, Hayirli A. 2016. Quality of eggs in different production systems. Czech Journal of Food Sciences, 34(4): 370-376. doi.org/10.17221/33/2016CJFS.

Yılmaz Dikmen BY, Ipek A, Şahan Ü, Sözcü A, Baycan SC. 2017. Impact of different housing systems and age of layers on egg quality characteristics. Turkish Journal of Veterinary and Animal Sciences, 41(1): 77-84. doi.org/10.3906/vet1604-71.

Żakowska-Biemans S, Tekień A. 2017. Free range, organic? Polish consumers preferences regarding information on farming system and nutritional enhancement of eggs: A discrete choice based experiment. Sustainability, 9(11): 1999. doi.org/10.3390/su9111999.

Zita L, Jeníková M, Härtlová H. 2018. Effect of housing system on egg quality and the concentration of cholesterol in egg yolk and blood of hens of native resources of the Czech Republic and Slovakia. Journal of Applied Poultry Research, 27(3): 380-8. doi.org/10.3382/japr/pfy009. 